\title{
ANALISIS GAYA HIDUP SEBAGAI FAKTOR RESIKO HIPERTENSI DI DESA MLIWIS CEPOGO BOYOLALI
}

\author{
Lilik Sriwiyati $^{1}$, Dwi Indriani ${ }^{2}$
}

\begin{abstract}
Background : hypertension is blood pressure with systolic pressure above $140 \mathrm{mmHg}$ and diastolic pressure above $90 \mathrm{mmHg}$. Hypertension risk factors vary widely. Healthy lifestyle, such as attention to body, mind, and a healthy soul can reduce the risk of hypertension. The purpose of this study was to analyze lifestyle as hypertension risk factor in Mliwis, Cepogo, Boyolali.

Methods of the research is a corelational study. Subjects of this research were Mliwis villagers. The samples were 46 responden selected by using purposive sampling method. Collecting data use questionnaire paper. Data analysis use logistic regresion test with $\mathrm{p}=0,05$

Results of this research is high salt eating habits is the most influential risk factor to hypertension, that is with value $p=0,013$, OR $35.181 ; \mathrm{Cl} 95 \% 2,096$ until 590,563. Then followed by variable smoking habit ( $p=0.017$, OR $24.920 ; \mathrm{Cl} 95 \% 1.758$ hingga 353.31) and sports habits $(\mathrm{p}=0.041$, OR $0.062 ; \mathrm{Cl} 95 \% 0.004$ hingga 0.893$)$. Variable habit of drinking alcohol, eating high fat and obesity have no effect on hypertension. Statistical test results of these variables are: drinking alcohol $p=0,079$, OR 19,003; Cl $95 \% 0,711$ until 507,940), eating high fat ( $\mathrm{p}=0,675$, OR 1,597; $\mathrm{Cl} 95 \% 0,179$ until 14,283$)$, obesity $(p=0,404$, OR 2,766; Cl $95 \% 0,253$ until 30,194). The value of Negelkerke R Square is $66.9 \%$.

Conclusion : lifestyle that increases the risk of hypertension is a high salt eating habits, smoking habits and exercise habits, while the habit of drinking alcohol, eating high fat and obesity have no effect increase the risk of hypertension on villagers of Mliwis Cepogo Boyolali.
\end{abstract}

Keywords: lifestyle, high salt eating habits, smoking habits, exercise habits, habit of drinking alcohol, eating high fat and obesity, hypertension

\section{PENDAHULUAN}

Hipertensi atau tekanan darah tinggi sering disebut sebagai the silent killer (penderita tidak tahu bahwa dirinya menderita hipertensi sebelum memeriksakan tekanan darahnya). Menurut Widyanto, Candra dan Triwibowo (2013) hipertensi adalah tekanan darah seseorang dengan tekanan sistolik di atas $140 \mathrm{mmHg}$ dan tekanan diastolik di atas $90 \mathrm{mmHg}$. Bila terjadi hipertensi terus menerus bisa memicu stroke, serangan jantung, dan merupakan penyebab utama gagal ginjal kronik (Purnomo, 2009). Hipertensi juga dikenal sebagai heterogeneouse group disease karena dapat menyerang siapa saja dari berbagai kelompok umur, sosial dan ekonomi. Hipertensi juga merupakan faktor resiko ketiga terbesar yang menyebabkan kematian dini karena dapat memicu terjadinya gagal jantung kongestif serta penyakit cerebrovaskuler (Widyanto, Candra dan Triwibowo, 2013).

Hasil penelitian Suoth, Bidjuni dan Malara (2014) di Puskesmas Kolongan Kecamatan Kalawat Kabupaten Minahasa Utara, jumlah pengidap penyakit hipertensi tahun 2012 berjumlah 1138. Pada bulan Januari sampai Oktober 2013 berjumlah 648 penderita penyakit 
hipertensi dari 25.149 jumlah penduduk Kecamatan.

Faktor resiko hipertensi sangat bervariasi. Hasil penelitian dari Yusuf, Fathurrahman dan Magdalena (2015), mengungkapkan bahwa gaya hidup yang sehat, seperti perhatian terhadap tubuh, pikiran dan jiwa yang sehat dapat menurunkan resiko hipertensi. Hidup yang sehat dan berkualitas tidak dapat tercapai begitu saja melainkan harus dilatih setiap hari. Sikap, perasaan dan pikiran mempengaruhi kesehatan seseorang. Pikiran yang berorientasi pada kesehatan adalah yang melihat dunia secara positif.

Desa Mliwis merupakan salah satu desa dimana sesuai hasil survei awal banyak warga yang mengalami hipertensi. Namun sampai saat ini belum diketahui faktor resiko secara statistik sehingga masyarakat lebih mudah mengalami hipertensi.

\section{TUJUAN PENELITIAN}

Tujuan penelitian ini adalah untuk menganalisis gaya hidup sebagai faktor resiko hipertensi di Desa Mliwis, Cepogo, Boyolali.

\section{METODE/DESAIN PENELITIAN}

Penelitian ini merupakan penelitian korelasi untuk mengetahui hubungan gaya hidup sebagai faktor resiko hipertensi di Desa Mliwis, Cepogo, Boyolali. Penelitian ini terdiri dari dua variabel yaitu gaya hidup (merokok, minum alkohol, pola makan, olahraga) sebagai variabel bebas (independent variable) dan hipertensi sebagai variabel terikat (dependent variable).

POPULASI, SAMPEL DAN TEHNIK SAMPLING

Populasi dalam penelitian ini adalah penduduk laki-laki Desa Mliwis, Cepogo, Boyolali yang berusia $>40$ tahun dengan jumlah 52 orang. Besar sampel pada penelitian ini adalah 46 orang yang diambil dengan teknik purposive sampling. Kriteria inklusi penelitian ini adalah laki-laki usia >40 tahun di Desa Mliwis, Cepogo, Boyolali dan bersedia menjadi responden. Sedangkan kriteria eksklusi penelitian ini adalah warga yang mempunyai riwayat hipertensi sekunder, gagal ginjal, diabetes melitus dan hipertiroid.

\section{HASIL PENELITIAN}

1. Karakteristik Responden

Tabel 1.

Distribusi Frekuensi Karakteristik Responden Berdasarkan Usia

\begin{tabular}{rcc}
\hline Umur (Th) & $f$ & $\%$ \\
\hline $40-49$ & 23 & 50 \\
$50-59$ & 11 & 23.9 \\
$60-69$ & 8 & 17.4 \\
$70-79$ & 4 & 8.7 \\
\hline Jumlah & 46 & 100 \\
\hline
\end{tabular}

Tabel di atas menunjukkan bahwa berdasarkan umur responden paling banyak berumur 40-49 tahun yaitu berjumlah 23 responden (50\%).

2. Distribusi Gaya Hidup

Tabel 2.

Distribusi Frekuensi Gaya Hidup

\begin{tabular}{cccccc}
\hline Faktor & $\begin{array}{c}\text { Kate } \\
\text { gori }\end{array}$ & $\begin{array}{c}\text { Hiper } \\
\text { tensi }\end{array}$ & $\%$ & Tidak & $\%$ \\
\hline Merokok & Ya & 19 & 82.6 & 11 & 47.8 \\
& tidak & 4 & 17.4 & 12 & 52.2 \\
Minum & Ya & 7 & 30.4 & 1 & 4.3 \\
alkohol & tidak & 16 & 69,6 & 22 & 95,7 \\
$\begin{array}{c}\text { Makan } \\
\text { tinggi }\end{array}$ & ya & 17 & 73.9 & 10 & 43.5 \\
lemak & tidak & 6 & 26.1 & 13 & 56.5 \\
$\begin{array}{c}\text { Makan } \\
\text { tinggi }\end{array}$ & ya & 15 & 65.2 & 6 & 26.1 \\
garam & tidak & 8 & 34.8 & 17 & 73.9 \\
$\begin{array}{c}\text { Obesitas } \\
\text { ya }\end{array}$ & 9 & 39.1 & 2 & 8.7 \\
Olah- & ya & 4 & 17.4 & 11 & 47.8 \\
raga & tidak & 19 & 82.6 & 12 & 52.2 \\
\hline
\end{tabular}


Berdasarkan tabel di atas dapat diamati bahwa berdasarkan faktor merokok terdapat 30 responden yang merokok, 19 diantaranya mengalami hipertensi. Berdasarkan faktor minum alkohol terdapat 8 responden yang minum alkohol, 7 diantaranya mengalami hipertensi. Berdasarkan faktor makan tinggi lemak terdapat 27 responden yang mempunyai kebiasaan makan tinggi lemak seperti gorengan dan santan, 17 diantaranya mengalami hipertensi. Berdasarkan faktor makan tinggi garam terdapat 21 responden yang mempunyai kebiasaan makan tinggi garam atau terbiasa dengan makanan yang asin, 15 diantaranya mengalami hipertensi. Berdasarkan faktor obesitas terdapat 10 responden yang mengalami obesitas, 7 diantaranya mengalami hipertensi. Berdasarkan faktor olah raga terdapat 15 responden yang rutin olah raga, 4 diantaranya mengalami hipertensi.

3. Analisis Gaya Hidup Sebagai Faktor Resiko Hipertensi

Tabel 3.

Analisis Bivariat Gaya Hidup Sebagai Faktor Resiko Hipertensi

\begin{tabular}{lc}
\hline \multicolumn{1}{c}{ Kategori } & $p$ value \\
\hline Merokok & 0.017 \\
Minum alkohol & 0.043 \\
Makan tinggi lemak & 0.040 \\
Makan tinggi garam & 0.010 \\
Obesitas & 0.025 \\
Olahraga & 0.033 \\
\hline
\end{tabular}

Berdasarkan hasil analisis bivariat semua faktor resiko hipertensi yang diteliti mempunyai nilai $\mathrm{p}<0.05$, sehingga semua faktor resiko tersebut dapat dimasukkan ke dalam analisis multivariat.
Adapun hasil analisa multivariat adalah sebagai berikut :

Tabel 4.

Analisis Multivariat Gaya Hidup Sebagai Faktor Resiko Hipertensi

\begin{tabular}{|c|c|c|c|}
\hline Kategori & OR & Cl $95 \%$ & $\begin{array}{c}p \\
\text { value }\end{array}$ \\
\hline Merokok & 24.920 & $1.758-353.31$ & 0.017 \\
\hline $\begin{array}{l}\text { Minum } \\
\text { alkohol }\end{array}$ & 19.003 & $0.711-507.940$ & 0.079 \\
\hline $\begin{array}{l}\text { Makan } \\
\text { tinggi lemak }\end{array}$ & 1.597 & $0.179-14.283$ & 0.675 \\
\hline $\begin{array}{l}\text { Makan } \\
\text { tinggi garam }\end{array}$ & 35.181 & $35.181-2.096$ & 0.013 \\
\hline Obesitas & 2.766 & $2.766-0.253$ & 0.404 \\
\hline Olahraga & 0.062 & $0.004-0.893$ & 0.041 \\
\hline
\end{tabular}

Tabel di atas menunjukkan variabel kebiasaan makan tinggi garam merupakan faktor resiko yang paling berpengaruh terhadap hipertensi, yaitu dengan nilai $p=0.013$, OR 35.181 ; Cl 95 $\% \quad 2.096$ hingga 590.563. Kemudian diikuti oleh variabel kebiasaan merokok $(p=0.017$, OR 24.920 ; Cl $95 \% 1.758$ hingga 353.31) dan kebiasaan olah raga ( $p=0.041$, OR 0.062 ; Cl $95 \% 0.004$ hingga 0.893).

Berdasarkan analisa multivariat variabel kebiasaan minum alkohol, makan tinggi lemak dan obesitas tidak berpengaruh terhadap hipertensi. Adapun nilai analisa masing-masing variabel tersebut adalah sebagai berikut : kebiasaan minum alkohol $\mathrm{p}=$ 0.079, OR 19.003 ; Cl $95 \%$ 0.711 hingga 507.940), makan tinggi lemak ( $p=0.675$, OR 1.597 ; Cl $95 \% 0.179$ hingga 14.283), obesitas ( $p=0.404$, OR 2.766 ; Cl $95 \% 0.253$ hingga 30.194 ).

Nilai Negelkerke $R$ Square sebesar $66.9 \%$ berarti proporsi varians gaya hidup sebagai faktor resiko hipertensi yang dapat dijelaskan dalam penelitian ini sebesar $66.9 \%$. 


\section{PEMBAHASAN}

Faktor-faktor yang terbukti sebagai faktor risiko hipertensi setelah dilakukan analisis multivariat dengan regresi logistik berganda pada penelitian ini yaitu kebiasaan makan tinggi garam yang merupakan faktor resiko yang paling berpengaruh terhadap hipertensi, kemudian diikuti oleh kebiasaan merokok dan olahraga.

1. Kebiasaan Makan Tinggi Garam Hasil analisa multivariat menggunakan uji regresi logistik ganda didapatkan hasil $p=0.013$ dan OR 35.181. Hal ini berarti responden yang mempunyai kebiasaan makan tinggi garam memiliki resiko terkena hipertensi 35,181 kali lebih besar bila dibandingkan dengan responden yang tidak mempunyai kebiasaan makan tinggi garam. Hasil analisis menunjukkan bahwa variabel kebiasaan makan tinggi garam merupakan faktor resiko hipertensi yang paling berpengaruh terhadap tekanan darah responden.

Natrium adalah kation utama cairan ekstraseluler sehingga mengatur volume ektraseluler dan plasma. Natrium penting dalam fungsi neuromuskular dan mempertahankan keseimbangan asam basa (Krummel dan Couch, 2008). Asupan natrium yang tinggi dapat mengakibatkan ion $\mathrm{Na}$ dalam bahan makanan diserap ke dalam pembuluh darah. Adanya ion $\mathrm{Na}$ di dalam darah akan mengakibatkan tubuh meretensi lebih banyak air untuk mempertahankan pengenceran elektrolit. $\mathrm{NaCl}$ tetap ekstraseluler sehingga cairan interstisial bisa terakumulasi dan volume plasma meningkat. Peningkatan volume plasma dalam waktu yang lama menyebabkan peningkatan volume sekuncup yang kronis karena peningkatan volume plasma direfleksikan dengan peningkatan volume diastolik akhir sehingga volume sekuncup dan tekanan darah meningkat (Yudha, Esty dan Dewi, 2008).

2. Kebiasaan Merokok

Hasil analisa multivariat menggunakan uji regresi logistik ganda didapatkan hasil $p=0.017$ dan OR 24.920. Hal ini berarti responden yang mempunyai kebiasaan merokok memiliki resiko terkena hipertensi 24.92 kali lebih besar bila dibandingkan dengan responden yang tidak mempunyai kebiasaan merokok. Menurut Widyanto, Candra dan Triwibowo (2013) merokok dapat meningkatkan tekanan darah dan denyut jantung melalui mekanisme sebagai berikut : 1) merangsang saraf simpatis untuk melepaskan norepineperine melalui saraf adrenergi dan meningkatkan catecolamine yang dikeluarkan melalui medula adrenal. 2) Merangsang kemoreseptor di arteri karotis dan aorta bodies dalam meningkatkan denyut jantung dan tekanan darah. 3) Secara langsung melalui otot jantung yang mempunyai efek inotropik (+) dan efek chonotropik.

3. Kebiasaan Olah Raga

Hasil analisa multivariat menggunakan uji regresi logistik ganda didapatkan hasil $p=0.041$ dan OR 0.062. Hal ini berarti responden yang mempunyai kebiasaan olah raga beresiko mengalami hipertensi 0.062 kali lebih rendah daripada responden yang tidak mempunyai kebiasaan olah raga.

Aktivitas olah raga yang dilakukan secara teratur dapat menurunkan tekanan darah pada individu yang mengalami hipertensi, termasuk yang mengalami obesitas. Peningkatan aktivitas fisik dapat menurunkan resistensi insulin, 
inaktivasi sistem saraf simpatik dan mencegah disfungsi vaskular, dimana dapat menyebabkan penurunan denyut nadi dan resistensi sistem vaskular sehingga menurunkan tekanan darah (Torrance, McGuire dan Lewanczuk, 2007). Penelitian yang dilakukan oleh Watts, Jones, dan Davis (2005) menunjukkan bahwa olahraga aerobik dapat menurunkan tekanan darah sistolik dan secara signifikan mengembalikan fungsi endotel. Seseorang yang kurang melakukan aktivitas olah raga menyebabkan tubuh kurang menggunakan energi yang tersimpan dalam tubuh.

4. Kebiasaan Makan Makanan Tinggi Lemak

Hasil analisa multivariat menggunakan uji regresi logistik ganda didapatkan hasil $\mathrm{p}=$ 0.675. Hal ini berarti kebiasaan makan makanan tinggi lemak tidak berpengaruh terhadap kejadian hipertensi. Hal ini diduga karena faktor kebiasaan makan makanan tinggi lemak bila dibandingkan dengan faktor resiko lain secara bersama-sama memiliki pengaruh yang lebih rendah. Akan tetapi berdasarkan analisa bivariat dengan nilai 0.040 dapat dikatakan bahwa kebiasaan makan makanan tinggi lemak berpengaruh terhadap kejadian hipertensi. Kondisi ini didukung oleh penelitian yang dilakukan oleh Martalina dan Muhammad (2012) yang menunjukkan bahwa secara signifikan asupan lemak merupakan faktor resiko hipertensi dengan resiko 4.3 kali lebih tinggi dibandingkan dengan asupan lemak normal. Lemak adalah cadangan energi tubuh terbesar (Murray, Grammer, dan Rodwell, 2009). Lemak memiliki densitas energi yang tinggi, sehingga dapat menyebabkan keseimbangan positif dan kelebihan tersebut akan disimpan dalam jaringan adiposa. Peningkatan jaringan adiposa akan meningkatkan leptin, sehingga memiliki pengaruh terhadap keseimbangan energi yang pada akhirnya dapat menyebabkan obesitas. Kadar adiponektin yang rendah, adanya aresistensi leptin, serta berbagai sitokin yang terlepas dari sel adiposa dan sel inflamasi yang menginfiltrasi jaringan lemak, menurunkan ambilan asam lemak bebas oleh mitokondria pada beberapa jaringan, menurunkan oksidasi asam lemak bebas, dan menyebabkan akumulasi asam lemak bebas intrasel. Kelebihan asam lemak bebas intrasel dapat memicu resistensi insulin, bahkan hiperinsulinemia dan hiperglikemia (Haris dan Tambunan, 2009). Resistensi insulin yang disertai dengan gangguan fungsi endotel pembuluh darah, dapat menyebabkan vasokonstriksi dan reabsorbsi natrium dari ginjal yang mengakibatkan hipertensi melalui penurunan nitric oxide yang menimbulkan vasodilatasi, peningkatan sensitivitas garam, dan peningkatan volme plasma (Murray, Grammer, dan Rodwell, 2009).

5. Obesitas

Hasil analisa multivariat menggunakan uji regresi logistik ganda didapatkan hasil $\mathrm{p}=$ 0.675. Hal ini berarti obesitas tidak berpengaruh terhadap kejadian hipertensi. Hal ini diduga karena faktor obesitas bila dibandingkan dengan faktor resiko lain secara bersama-sama memiliki pengaruh yang lebih rendah. Akan tetapi berdasarkan analisa bivariat dengan nilai 0.025 dapat dikatakan bahwa obesitas berpengaruh terhadap 
kejadian hipertensi. Kondisi ini didukung oleh penelitian yang dilakukan oleh Kartikasari (2012) yang menunjukkan bahwa orang dengan obesitas memiliki risiko terserang hipertensi 9.051 kali lebih besar dibandingkan orang yang tidak obesitas. Obesitas sangat erat kaitannya dengan pola makan yang tidak seimbang. Dimana seseorang lebih banyak mengkonsumsi lemak dan protein tanpa memperhatikan serat. Kelebihan berat badan meningkatkan risiko terjadinya penyakit kardiovaskular karena beberapa sebab. Makin besar massa tubuh, makin banyak darah yang dibutuhkan untuk memasok oksigen dan makanan ke jaringan tubuh. Ini berarti volume darah yang beredar melalui pembuluh darah menjadi meningkat sehingga memberi tekanan lebih besar pada dinding arteri. Seseorang yang gemuk lebih mudah terkena hipertensi.

6. Kebiasaan Minum Alkohol

Hasil analisa multivariat menggunakan uji regresi logistik ganda didapatkan hasil $\mathrm{p}=$ 0.079 . Hal ini berarti kebiasaan minum alkohol tidak berpengaruh terhadap kejadian hipertensi. Menurut Widyanto, Candra dan Triwibowo (2013) pengguna alkohol secara berlebihan dapat meningkatkan tekanan darah, dengan cara meningkatkan katekolamin plasma. Dalam penelitian ini seberapa banyak responden minum alkohol tidak diukur dengan lebih detail, sehingga hal ini yang memungkinkan hasil penelitian ini menunjukkan bahwa alkohol tidak berpengaruh terhadap hipertensi.

\section{KESIMPULAN}

1. Gaya hidup yang berpengaruh meningkatkan resiko hipertensi adalah kebiasaan makan tinggi garam, kebiasaan merokok dan kebiasaan olehraga, sedangkan kebiasaan minum alkohol, makan tinggi lemak dan obesitas tidak berpengaruh meningkatkan resiko hipertensi.

2. Kebiasaan makan tinggi garam merupakan faktor resiko hipertensi yang paling berpengaruh, orang yang mempunyai kebiasaan makan tinggi garam memiliki resiko terkena hipertensi 35.181 kali lebih besar bila dibandingkan dengan orang yang tidak mempunyai kebiasaan makan tinggi garam.

3. Kebiasaan merokok merupakan faktor ke-2 penyebab hipertensi, orang yang mempunyai kebiasaan merokok memiliki resiko terkena hipertensi 24.92 kali lebih besar bila dibandingkan dengan orang yang tidak mempunyai kebiasaan merokok.

4. Kebiasaan olah raga merupakan faktor ke-3 penyebab hipertensi, orang yang mempunyai kebiasaan olah raga beresiko mengalami hipertensi 0.062 kali lebih rendah daripada orang yang tidak mempunyai kebiasaan olah raga.

\section{SARAN}

1. Bagi warga masyarakat diharapkan untuk menghindari faktor-faktor yang dapat meningkatkan kejadian hipertensi yaitu makan makanan tinggi garam, merokok dan kurang olah raga, supaya dapat terhindar dari hipertensi atau bagi warga yang sudah mengalami hipertensi dapat terhindar dari komplikasi hipertensi.

2. Bagi tenaga kesehatan diharapkan dapat meningkatkan pemberian informasi kepada warga terkait dengan faktorfaktor resiko hipertensi. 
DAFTAR PUSTAKA

Haris, S. dan T. Tambunan. 2009. Hipertensi pada Sindrom Metabolik.https://saripediatri.org/i ndex.php/saripediatri/article/view/577/513. Diakses pada tanggal 28 Maret 2017

Kartikasari, A. N. 2012. Faktor Risiko Hipertensi pada Masyarakat di Desa Kabongan Kidul, Kabupaten Rembang. Jurnal Media Medika Muda. Diakses pada tanggal 28 Maret 2017

Krummel, D. A. dan S. C. Couch 2008. Medical Nutrition Therapy in Hypertension. Saunders Elsevier, St Louis.

Martalina, T. dan S. Muhammad. 2012. Asupan Tinggi dan Aktivitas Olahraga sebagai Faktor Risiko Terjadinya Hipertensi Obesitik pada Remaja Awal. Journal of Nutrition College, Volume 1, Nomor 1. Diakses pada tanggal 30 Maret 2017

Murray, R. K., D. K. Grammer dan V. Rodwell. 2009. Biokimia Harper. EGC, Jakarta.

Purnomo, H. 2009. Penyakit yang Paling Mematikan. Buana Pustaka, Jakarta.

South, M., H. Bidjuni dan R. T. Malara. 2014. Hubungan Gaya Hidup dengan Kejadian Hipertensi di Pukesmas Kolongan Kecamatan Kalawat Kabupaten Minahasa Utara. Manado. Ejournal Keperawatan (e-Kp) Volume 2 Nomor 1. Diakses pada tanggal 28 Maret 2017
Torrance, B., A. McGuire dan Lewanczuk. 2007. Overweight, Physical Activity and High Blood Pressure in Children : a Review of the Literature. https://www.ncbi.nlm.nih.gov/pmc /articles/PMC1994042/. Diakses pada tanggal 30 Maret 2017

Watts, K., T. W. Jones dan E. A. Davis. 2005. Exercise Training in Obese Children and Adolescents : Current Concepts. https://www.ncbi.nlm.nih.gov/ pubmed/15896088. Diakses pada tanggal 28 Maret 2017

Widyanto, F. Candra dan C. Triwibowo. 2013. Trend Penyakit Saat Ini. Trans Info Media, Jakarta.

Yudha, K., W. Esty dan Y. Dewi. 2008. Handbook of Pathophysiology. Lippincott Williams \& Wilkins, USA.

Yusuf, A., Fathurrahman, dan Magdalena. 2015. Hubungan Gaya Hidup dengan Hipertensi pada Pengunjung Puskesmas Teluk Dalam Banjarmasin. Banjarmasin.http://www.ejurnalsk alakesehatanpoltekkesbjm.com/index.php/JSK /login/signln. Diakses pada tanggal 28 Maret 2017

${ }^{1}$ Dosen Akper Panti Kosala

Surakarta

${ }^{2}$ Mahasiswa Akper Panti Kosala Surakarta 